\title{
デジタルカメラを用いた斜面崩轘・地滑りの監視システムの䦎発・
}

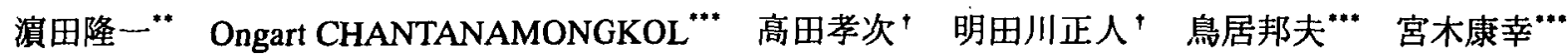

Monitoring method for landslide and slope collapse using precision digital camera

Ryuichi HAMADA, Ongart CHANTANAMONGKOL, Kouji TAKADA, Masato AKETAGAWA, Kunio TORII and Yasuyuki MIYAKI

There are a lot of dangerous sloped grounds, includes rock walls, by sides of roads, railways and buildings in JAPAN. In order to prevent accidental disasters, e.g. landslides on the slope surface, the surface movement of the ground must be strictly and continuously monitored. The conventional monitoring method using targets or clinometers on the slopes requires expensive costs, huge manpower and dangerous operation on the slope. This paper shows a new monitoring method for the landslide or slope collapse, requires no targets, using a precision digital camera and image processing algorithms. Serial still images of the slope are firstly taken with the digital camera with a constant time interval. Each image is divided into small block elements. Using a block matching method, all the blocks in the image previously taken are scanned and compared in some search areas in the image subsequently taken, and movement vectors of all the blocks, which means the slope slides or deformations, can be calculated. An image subtraction function and a cross correlation method are utilized as assessment functions in the block matching method. The proposed method is applied to real images of the rock wall collapse and movement vectors are calculated. Small early translational deformation of the rock can be calculated with the method. This result shows a feasibility of the method for monitoring landslides.

Key words : digital camera, landslide, monitoring, image processing, block matching

\section{1. 楮䡒}

長大な人工あるいは自然構造物の各部位の 3 次元的な位㯰 や変位・変形を精密に計測する手法が必要となりつつある ${ }^{1}$. 例えば，崩壊や地すべりの可能性のある斜面の各部位の位置 や変位を精密にモニターし，その結果，もし地滑りの前兆を 捉えることが出来れば，災害の被害を末然に防いだり，ある いはそれを最小限にすることが可能になる，山国でかつ地震 国である日本にとって，斜面崩壊危険区域の監視を行い，事 前に危険を通報することは，その区域の鉄道・車道あるいは 建物にとって安全対策上重要で，緊急の課題である。

現在，このような斜面崩猿や地滑り等が発生する可能性の ある危険斜面の監視法としては，(1) 標柱（ターゲット）・傾

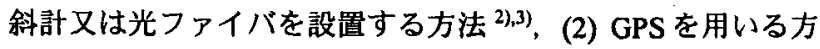
法 ${ }^{4), 5)}$ ，(3) 衛星画像を用いる方法 6)，など，が提案あるいは 実用化されている．(1)の方法は狭い範囲を高精度な計測が可 能だが，機器やセンサを斜面に設置する手間や危険を伴う. また，(2)，(3)の方法は，広範囲の計測が可能だが，専用の高 価な機器の使用を要する.

本報では，崩壊・地滑りの危険のある斜面に特に何も設置 せず，斜面そのものを高解像度のデジタルカメラで連続撮影 し，これらの画像にブロックマッチング法7)を適用して斜面

\footnotetext{
* 原稿受付 平成 13 年 4 月 17 日

** 学生会員 長岡技術科学大学大学院 (現，ソ二-国分(株)；国分市野口北 5-1)

***. 長岡技術科学大学 (長岡市上富岡町 1603-1)

$\dagger$ 正会員 長岡技術科学大学
}

崩壀の監視を行うシステムの開発を目的とする. 特に斜面崩 壊のなかでも地滑りなどの比較的移動速度の遅い場合の初期 移動検出法の開発を目指す。

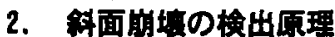

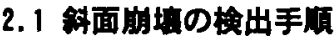

本研究では，固定されたデジタルカメラで撮影した対象斜 面の連続静止画にブロックマッチング法を適用することで斜 面崩壊の初期段階の変位検出を行う，以下に検出計測手順を 記す。

（1）対象斜面を水平・垂直画素 $M \times N$ pixel のデジタルカ メラを用いて一定時間間隔で撮影する．直前と現在の画 像の強度分布を，それぞれ $I_{k}(i, j) ， I_{k+1}(i, j)$ とする.ただ

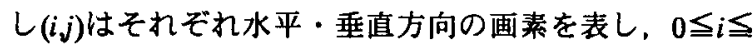
$M-1,0 \leqq j \leqq N-1$ とする.

(2) 直前の画像 $I_{k}(i, j)$ を図 1(a)に示すように水平・垂直方向 にそれぞれ $a \times b$ 分割し，合計 $a \times b$ 個の小ブロックを形 成する.ここで, ブロックの大きさを $m \times n$ pixel とする. この小ブロックの強度分布を $B_{k}(s, t ; i, j)$ と表す. $(s, t)$ は小 ブロックの水平・垂值方向の分割番号を示し， $0 \leqq s \leqq a-1$, $0 \leqq t \leqq b-1$ とする

(3) 直前画像中の小ブロック $B_{k}(s, t ; i, j)$ 自体を斜面の目標物 と見なし，現在の画像 $I_{k+1}$ の定められた探索筝囲内で 図 1(b)に示すように，これと同じ大きさのブロックを切 り出し，後述するブロックマッチングを行う．切り出す ブロックを探索範囲内で順次水平・垂值方向に 1pixel ず つスキャンし，ブロックマッチングの評価式より，最も 


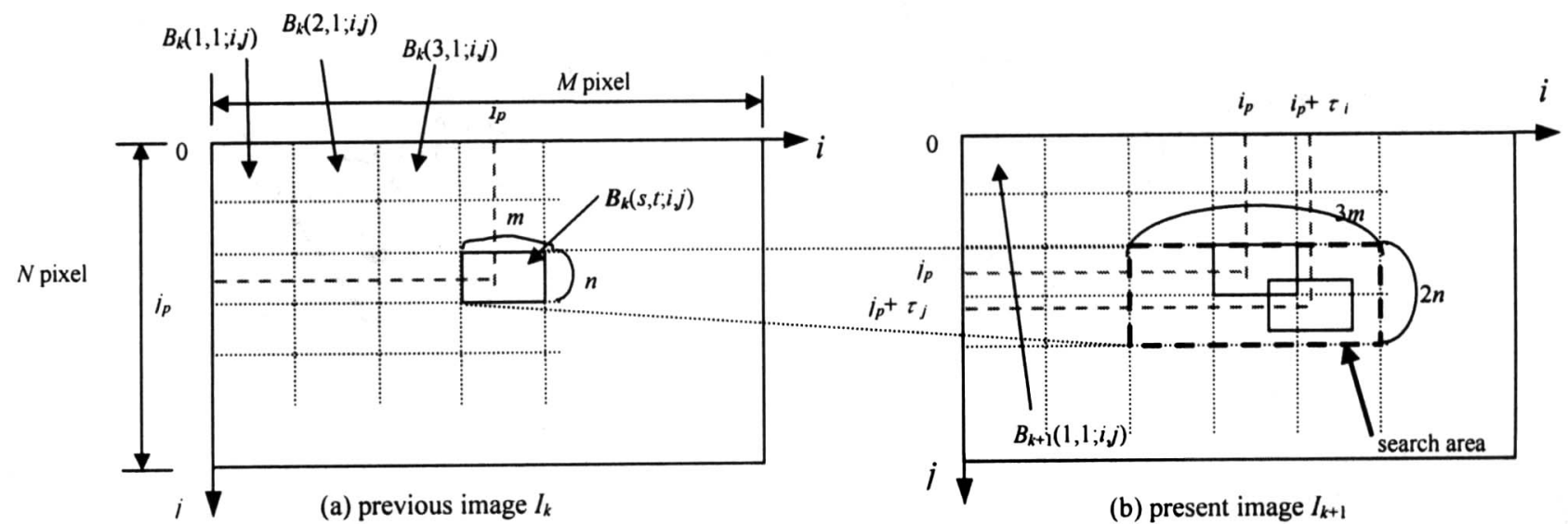

Fig.1 Block division and matching

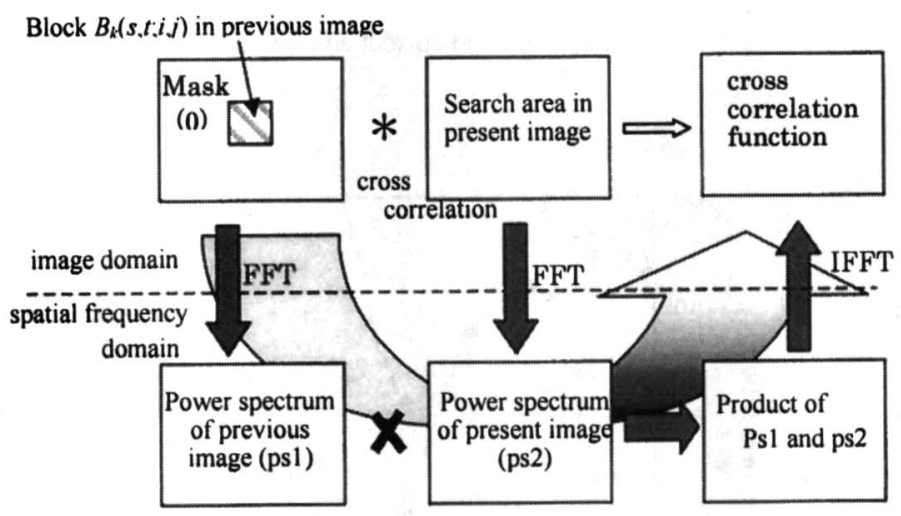

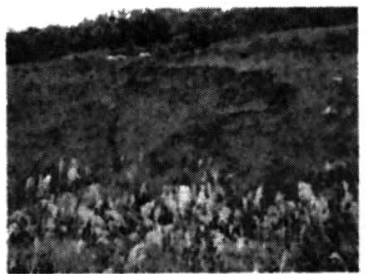

(a) $I_{k}$

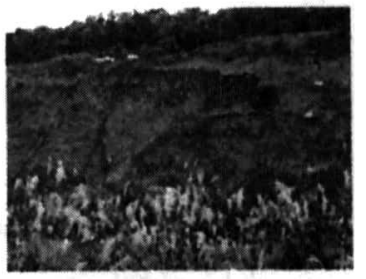

(b) $I_{k+1}$

Fig.3 Lateral shifted pictures taken with shifted camera

Fig.2 Cross correlation calculation procedure

類似度の高い移動先を求め, そのときの水平垂直方向の 横ずらし変位をこの小ブロックの移動ベクトルとする. 本報では初期移動の検出を目指しているので図 1(b)に示 すとおり, 移動探索範囲は小さく, 小ブロックの中心位 置 $\left(i_{p} j_{p}\right)$ を中心として水平垂直方向にそれぞれ $3 \times 2$ ブロ ック $(=3 m \times 2 n$ pixel $)$ とする. 対象ブロックが画像の下 端, 上端にある場合はそれぞれ探索範囲を $2 \times 1$ ブロック， $2 \times 2$ ブロックとした.

この移動探索を全ての小ブロックについて実行し，その 移動量を各小ブロックの中心位置 $\left(i_{p}, j_{p}\right)$ を始点としてべ クトル表示する.

(4) (3)で得られた各小ブロックの移動ベクトル（の絶対 值）が，許容值以上であれば，斜面崩壊の前兆として警 報を発する。

(5) 次画像 $I_{k+2}(i, j)$ を撮影し, $I_{k+1}(i, j)$ との比較を $(1) \sim(4) 0$ 手順で繰り返す.

\section{2 ブロックマッチングの評価法}

本報ではブロックマッチングの評価法として，(A) 比較す る 2 個の小ブロックの対応する画素の強度の差分を小ブロッ クの画素全てで総和し比較する方法 (以下差分法と略す), (B) 対応寸る 2 個の小ブロックの相互相関を計算し比較する方法 (以下相関法と略す) を実行し比較した。 以下にそれらの評 価式を示す.

\section{(A) 差分法の評価式}

垂直・水平方向の横ずらし変位を $\left(\tau_{i}, \tau_{j}\right)$ とすると, 小 ブロック $B_{k}(s, t ; i, j)$ の最も確からしい(すなわち類似度の高 い)移動先は，次式を最小にする $\left(\tau_{i}, \tau_{j}\right)$ をちえるもとし た.

$S_{k}\left(s, t, \tau_{i}, \tau_{j}\right)=\sum_{i=s m}^{(s+1) m-1} \sum_{j=m}^{(t+1) n-1}\left|B_{k}(s, t, i, j)-I_{k+1}\left(i+\tau_{i}, j+\tau_{j}\right)\right|$

(B) 相関法の評価式

相関法による評価関数は,

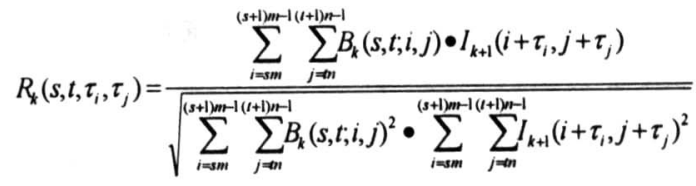

を採用し, 最も確からしい移動先はこの関数が最大となる 横ずらし変位 $\left(\tau_{i}, \tau_{j}\right)$ とする. 実際の計算は式(2)を直接計 算せず, 相互相関が 2 個の関数のフーリエ変換の積の逆フ 一リエ変換で与えられる事を利用し, 計算時間の短縮を図 った. 図 2 の太線で示すような手順で相互相関係数分布を 求め, 最大值を有する横ずらし変位 $\left(\tau_{i}, \tau_{j}\right)$ を移動べクト ルと判定した，同図において前画像の対象ブロックの周り に強度值が 0 となるマスクを探索範囲と同じ大きさとなる よう配置し, 前画像と現画像ともに同じ大きさの簀囲を高 


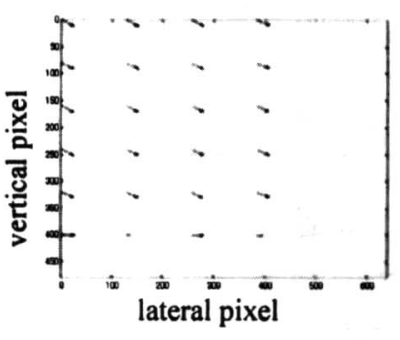

a) $128 \times 80$ pixel

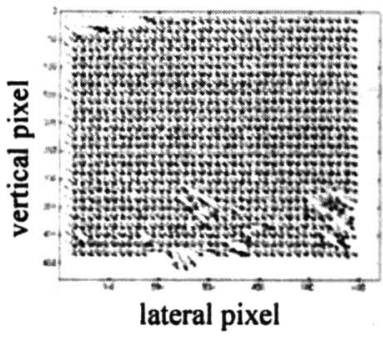

c) $16 \times 16$ pixel

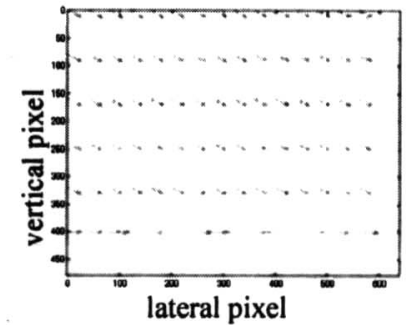

b) $40 \times 80$ pixel

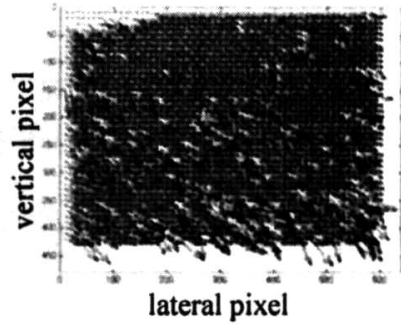

d) $10 \times 10$ pixel
Fig.4 Relationship between moving vectors and block size

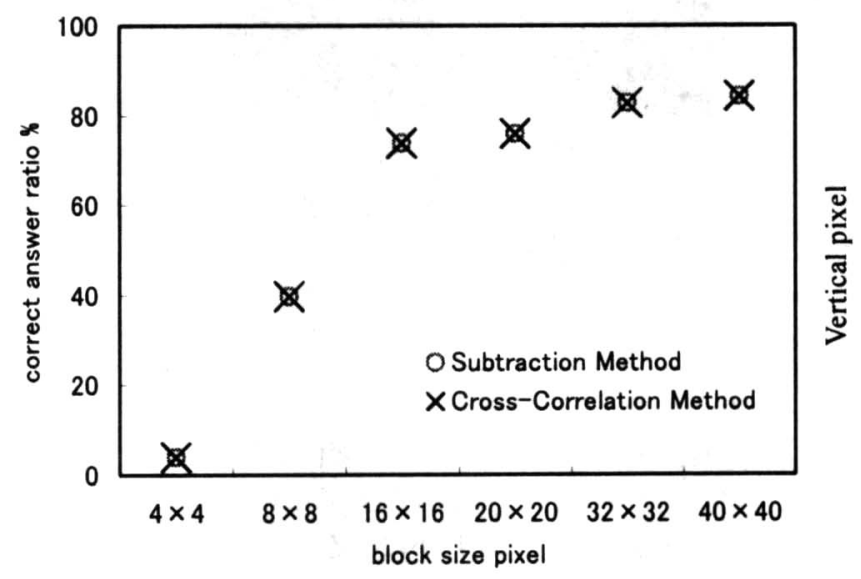

Fig.5 Relationship between block size and correct answer ratio

速フーリエ変換し，これらを乗算したのち逆フーリエ変換を 行い相関係数分布を求める. フーリエ変換を使うことにより, 差分法に比べ計算時間を大幅に短縮する事ができる.

\section{3. 予備実験（ブロックサイズと判定基準の決定）}

提案した手法を有効にするためには，適正なブロックサイ ズとマッチングの判定基準を設定する必要がある. ブロック の大きさが小さいほどより細かい斜面の移動を捉えることが できるが，誤認識をする可能性もある.

デジタルカメラ(Nikon COOLPIX950一設定画素: $640 \times 480$ pixel)を平行移動させ斜面の画像を 2 枚撮影し, 擬似的に斜面 全体が平行移動した画像を得, 適正なブロックサイズと移動 の判定基準の検討を行った. 図 3 は, カメラを平行移動させ て, $34 \mathrm{~m}$ 先の斜面を $\mathrm{f}=38 \mathrm{~mm}$ のレンズで撮影したものである.

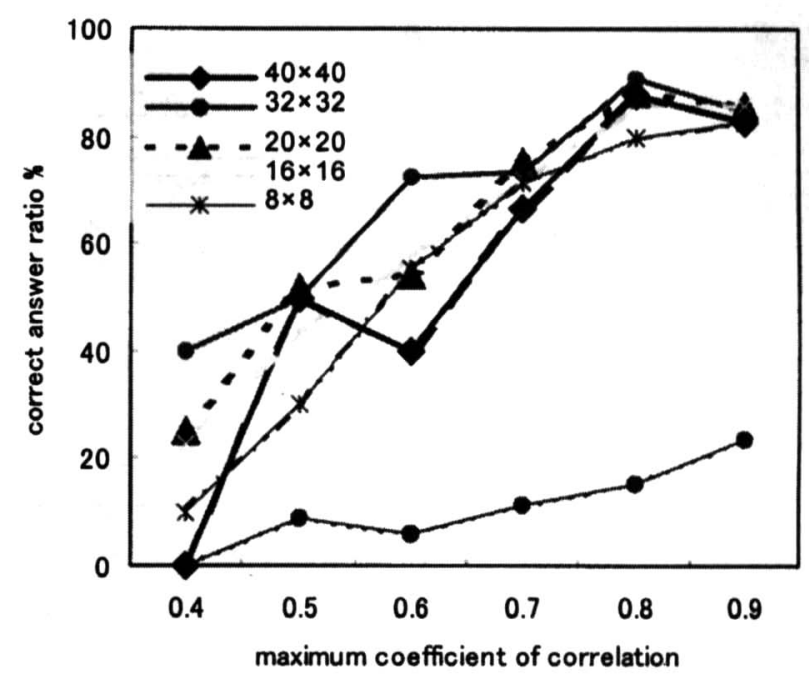

Fig.6 Relationship between maximum coefficient of cross correlation and correct answer ratio

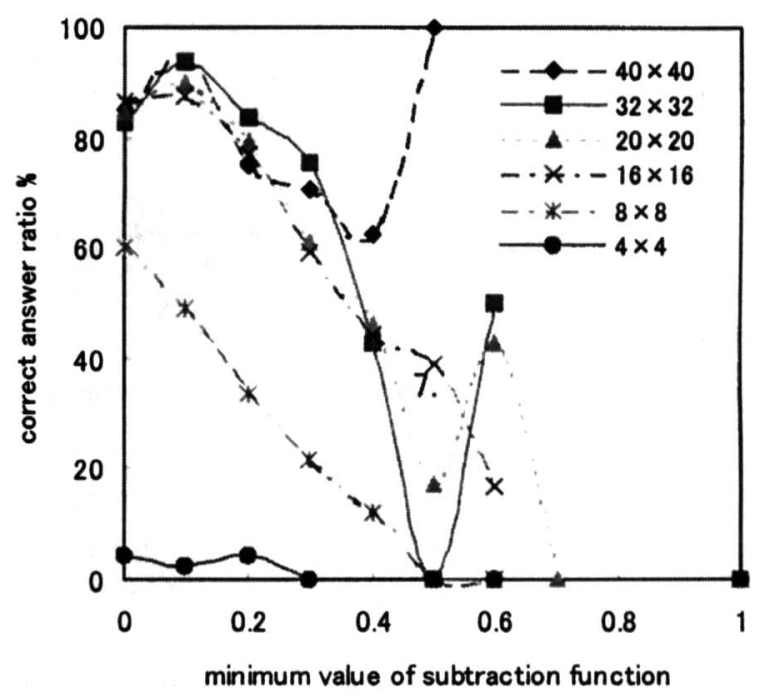

Fig.7 Relationship between minimum value of subtraction function and correct answer ratio

このときの解像度は, 1 pixel 当り $22 \mathrm{~mm}$ である.

ブロックサイズを $(128 \times 80),(40 \times 80),(16 \times 16),(10 \times 10)$ と変えた場合の相関法による移動量の計算結果を図 4 a) d ) に示す. 図中の矢印はブロックの移動ベクトルを表す。この 実験において提案した両手法は，検出した移動べクトルが画 面上部で全く等しかった．図 4 a)，b）において下部（主に草 木）で一定した移動ベクトルが計算されないのは風の影響で 草が動いているためと思われる. 図 4 a)，b）では，画面下部 を除けばいずれの場合も，計算で得た移動べクトルはカメラ を平行移動したことによる物理的な移動ベクトルとほぼ同じ であり，正しく移動を認識していると考えられる．対象ブロ ックが小さくなるにつれ，同図 c) で少し移動べクトルに乱れ が現れ, 同図 d) になると乱れが大きくなっている事が判る.

ブロックサイズの大きさを変えたとき移動量の測定結果が, カメラを平行移動した量と合致している場合を正解であると 
判断して，差分法と相関法におけるブロックサイズと正解率 の関係を図 5 に示す. 2 つの手法による正解率はブロックサ イズに関係なくほほ一致した．図 5 より,ブロックサイズが

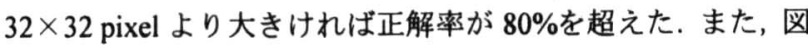
6 に, 相関法においてブロックサイズの大小をパラメータと して最大相関係数值と正解率の関係を示す. 同様に図 7 に差 分法においてブロックサイズの大きさをパラメータとして最 小差分総和値と正解率の関係を示す. 図 6,7 によりブロック サイズが $32 \times 32$ pixel で正解率が $80 \%$ 以上となるのは相関法, 差分法で最大相関係数と最小差分総和値がそれぞれ 0.8 以上, 0.2 以下となることが判った. 正解の判定基淮は, この結果よ りブロックサイズが $32 \times 32$ pixel の場合は, 判定基準は相関 法で 0.8 以上, 差分法で 0.2 以下と設定する.

\section{4. 斜面崩壊画像への適用}

本計測手法を岩盤崩壊を撮影した画像に適用した，適用画 像は, 平成 11 年 3 月に和歌山県西牟婁郡すさみ町での岩盤崩 壊を捉えたビデオ画像(図 8 : 国土交通省土木研究所提供一連 続静止画像 18 枚, BITMAP $640 \times 480$ pixel, カラー256 階調)

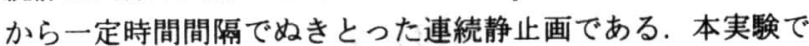
は，前処理としてカラー画像をグレースケール画像への変換
を行った. ブロックサイズは $32 \times 32$ pixel, 判定基準は相互相 関法, 差分法でそれぞれ 0.8, 0.2 とした. なお, 同図での 1 pixel は約 $40 \mathrm{~mm}$ である。

図 9 に相関法にて移動べクトルを計算した結果を示す. 1 枚の移動ベクトル分布の計算時間は計算機（Pentium III $450 \mathrm{MHz}$ ) で 50 秒であった. 図 10 に提案した 2 個の手法の正 解率を示した. ここで正解率は, 全てのブロックの移動を目 視で確認し，計算結果と比較し決定した。 図 9 a)に示したよ うに崩壊開始 $0 \mathrm{~s}$ と $0.25 \mathrm{~s}$ の画像に提案した 2 手法を適用した 結果, いずれの手法でも斜面の初期移動（画像上で lpixel） を検出することができた，また，図 9a)，b)と順次斜面が崩壊 していく様子もこの結果から判る. 差分法で行った場合も同 様に崩壊開始初期の岩盤が平行移動をしている段階を検出す ることができた．しかし，図 9c)，d)に示したように崩壊が進 んでいくと岩盤が変形したり, 回転運動が加わり, 両手法の 結果が相異し正確率が低下した. 図 10 に示したように移動べ クトル検出の正解率では若干，相関法の方が優れていた．本 報では図 8 に示した急速に崩壊する画像に提案した手法を適 応したが，地滑りなどの比較的ゆっくり変動する場合におい ても有効であると考える.

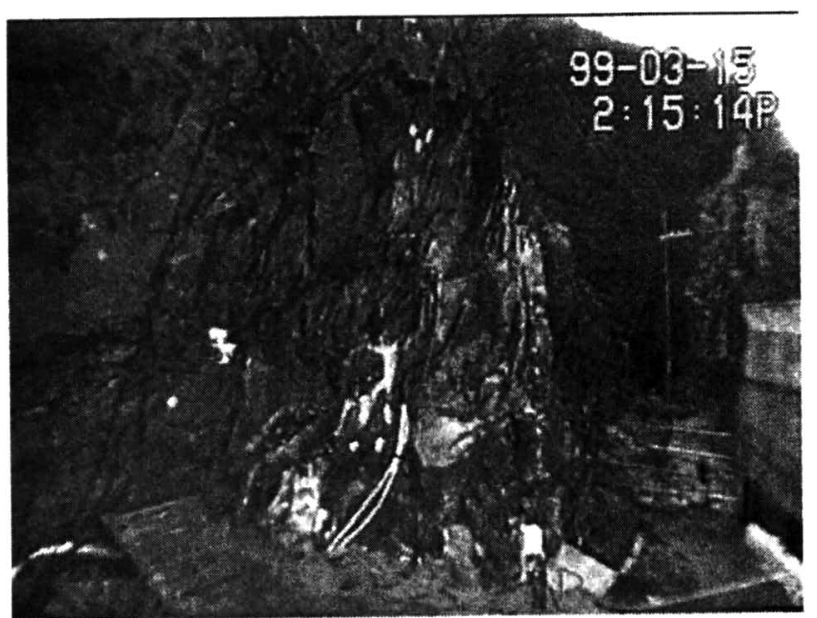

a) The collapse beginning $(0 \mathrm{~s})$

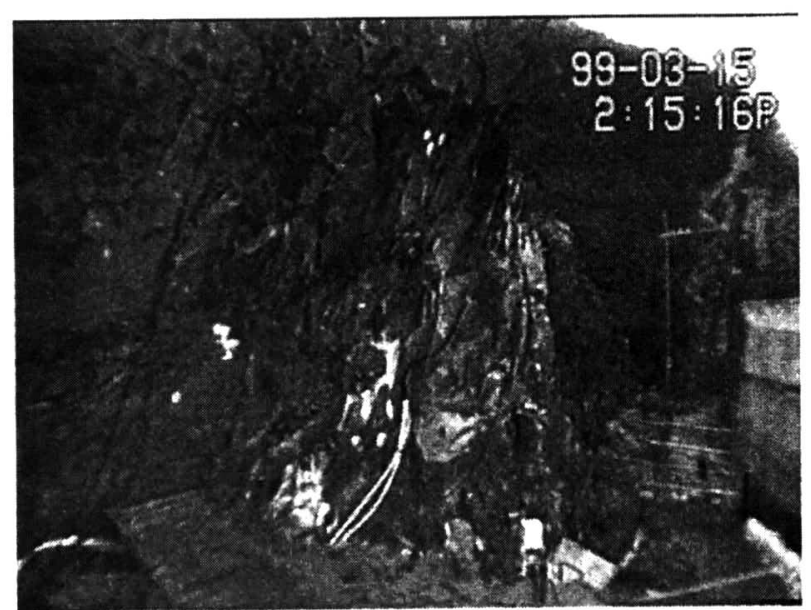

c) 2 second later

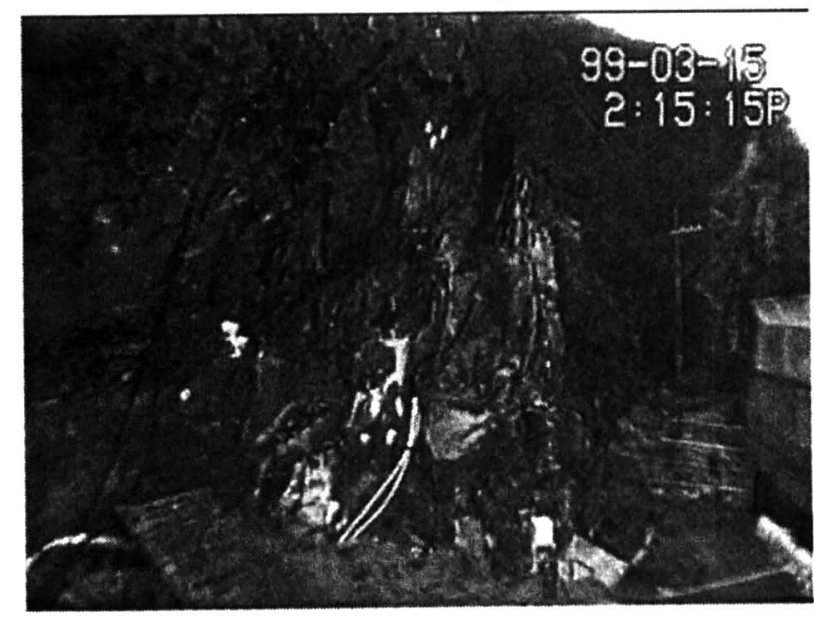

b) 1 second later

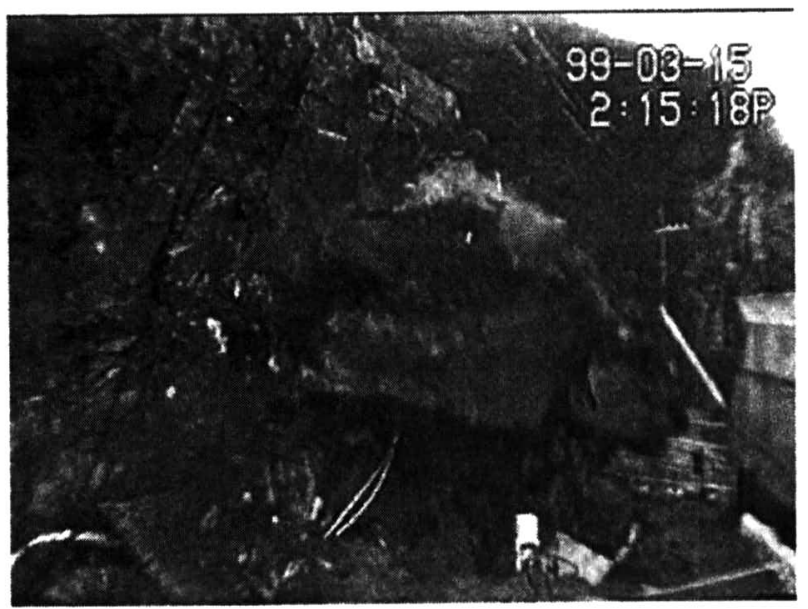

d) 4 second later

Fig.8 A Series of still image for rock wall collapse 


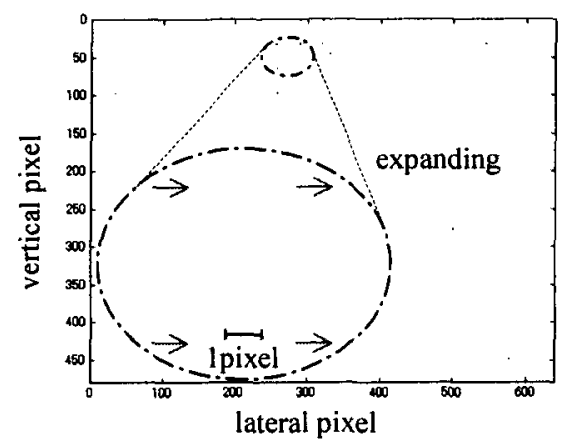

a) $0-0.25 \mathrm{~s}$

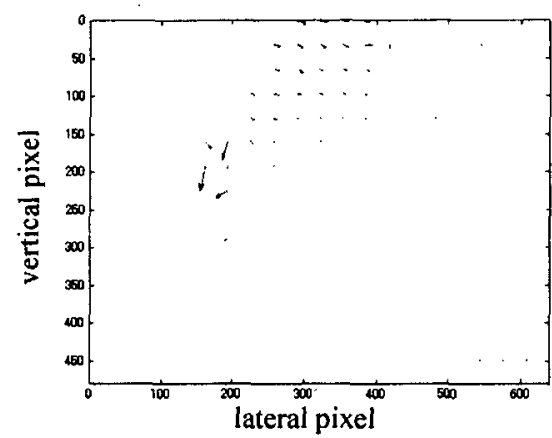

c) $0.5-0.75 \mathrm{~s}$

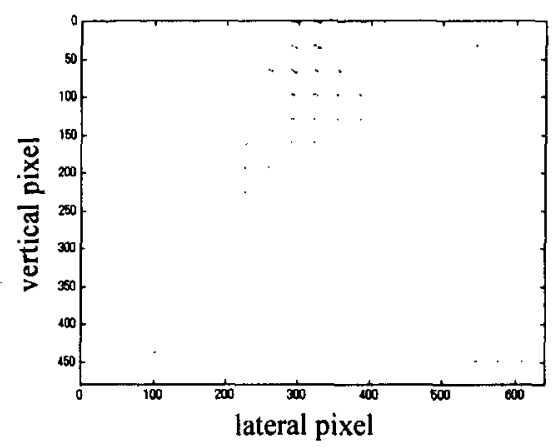

b) $0.25 \cdot 0.5 \mathrm{~s}$

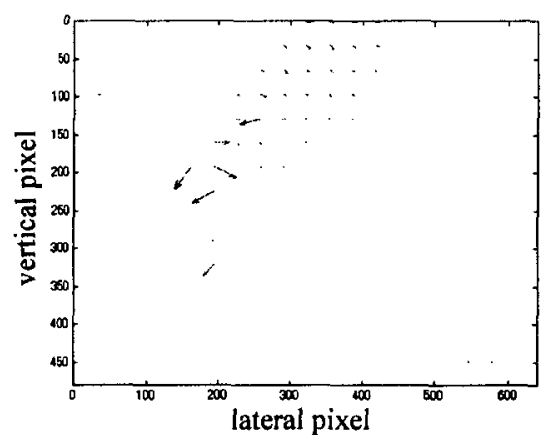

d) $0.75-1 \mathrm{~s}$

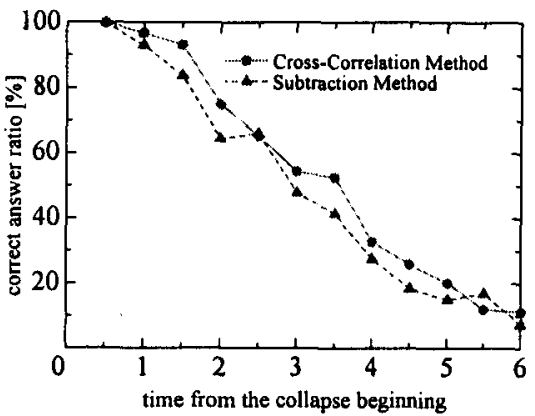

Fig.10 Relationship between the time from the collapse beginning and correct answer ratio

\section{影 辞}

本研究の一部は, 平成 11 年度セコ 么科学技術振興財団助成金で行われ たことを記し，謝意を表します。ビ デオ画像を提供して頂いた国土交通 省土木研究所に感謝します.

参考 文 献

1) 高田 孝次, 小櫻 義隆, 鳥居 邦 夫, 明田川正人：網橋用大型部材の 測定, 精密工学会誌 58-05, (1992)

\section{5. 結言と今後の課題}

本研究によって得られた結果を以下にまとめる.

1) デジタルカメラで撮影した斜面の連続画像から，斜面崩壊 を険知する方法を提案した．本方法は，画像を小ブロック に分割し，連続撮影した 2 画面間で，類似度の高いブロッ クをブロックマッチング法によって検出し対応させるこ とにより対象斜面の変位を追跡するもので，特別な標柱の 設置を必要としない.

2)岩盤崩壊を捉えたビデオ画像に提案した手法を適用した. 提案した岩盤崩壊の初期段階を明瞭に検出することがで き，手法の有效性を確認することができた。

3) ブロックマッチングの評価関数として相関法と差分法を比 較した結果, 判定の正確さ、計算時間のいずれにおいても 相関法がやや優れていた。

上記の結論を踏まえた上で今後の課題は，1) 平行移動のみ でなく斜面が変形したり，回転運動をした場合の検出アルゴ リズムの閶発．2）奏際に現地に装置を設置し，遠隔計測を行 うシステム開発，等が挙げられる.
2）樅野 雅哉，鳥居 邦夫，宮木 康幸: CCDカメラを用いた 斜面監視システムの三俣斜面一の適用，土木学会第 55 回 年次学術講演会講演概要集, VI-157，(2000)

3）日下部 祐基, 池田 憲二, 中井 健司, 川瀬良司, 㙁野康 浩：光ファイバセンサによる現地岩盤斜面計測，士木学 会第 55 回年次学術講演会講演概要集, VI-170, (2000)

4）櫻井春輔，清水則一；皿海章雄，古谷茂也：GPS に上る 切り取り斜面の変位測定, 土木学会論文集, No.475, III-24, (1993), 137-142

5）松田浩朗，西村好恵，清水則一，板尾和男：長大斜面に おける GPSによる変位計測, 土木学会第 55 回年次学術講 演会講演概要集， III-A192，(2000)

6)河邑置, 辻子 裕二: 衛星画像による地震時斜面崩壊形態 および崩壊規模の険出方法に関する研究，土木学会論文 集，597/IV-40，(1998)，11-20

7) 鄭文涛, 鹿喰義明，田中豊，湯山一郎：時空間ブロック マッチング法による動画像の動きベクトル場推定，電子 情報通信学会論文誌，J-81-D-II，(1998)，1736-1743

8）橋本基ほか：パソコンによる動画像処理 森北出版株式 会社 